\title{
Sciendo
}

Acta Veterinaria-Beograd 2021, 71 (1), 13-31

Research article

UDK: 636.8.09:616-006.3

DOI: $10.2478 /$ acve-2021-0002

\section{EXPRESSION OF PLATELET DERIVED GROWTH FACTOR A, ITS RECEPTOR, AND INTEGRIN SUBUNIT ALPHA V IN FELINE INJECTION-SITE SARCOMAS}

\author{
ISHTIAQ Ahmed ${ }^{1}$, SOZMEN Mahmut²* \\ ${ }^{1}$ Department of Pathobiology, College of Veterinary and Animal Sciences, Jhang, Sub-campus of \\ University of Veterinary and Animal Sciences, Lahore, Pakistan; ${ }^{2}$ Department of Pathology, Faculty of \\ Veterinary Medicine, Ondokuz Mayis University, Kurupelit, Samsun, Turkey
}

(Received 09 September 2020, Accepted 18 February 2021)

\begin{abstract}
Injection-site sarcomas are considered an important entity in veterinary oncology, especially in cats. The current study investigated the immunohistochemical expression of platelet-derived growth factor A (PDGFA), platelet-derived growth factor receptor- $\alpha$ (PDGFR- $\alpha$ ), and integrin alpha subunit $\mathrm{v}$ in feline injection-site sarcomas (FISS). A total of 14 paraffin-embedded tissue samples previously diagnosed as soft tissue sarcomas were selected from the departmental archive and sectioned at $5 \mu \mathrm{m}$ using a microtome. Tissue sections were stained with Hematoxylin \& Eosin, Alcian blue-Periodic Acid Schiff (AB-PAS), Masson's Trichrome, and immunohistochemically for PDGFA, PDGR- $\alpha$, and integrin alpha v. The majority of the tumors were fibrosarcomas $(n=13 / 14)$, except one case of myxoid liposarcoma. The tumors occurred at sites commonly used for injections or vaccine administration. Histologically, tumors were characterized by peripheral infiltration of mononuclear cells mainly lymphocytes, variable sized central necrotic areas, and many multinucleated tumor giant cells. AB-PAS staining revealed the presence of myxoid or mucinous areas in (8/14) tumors while trichrome staining demonstrated a variable amount of collagenous stroma in 12/14 tumors. Vimentin immunoreactivity was observed in all the tumors while smooth muscle actin and muscle actin staining was noticed in four and two cases, respectively. PDGFA and PDGFR- $\alpha$ immunoexpression was observed in all 14 cases while integrin alpha $\mathrm{v}$ in 13/14 cases. The results of the current study indicate that fibrosarcoma is the major morphologic phenotype of FISS. The PDGFA, its receptor, and integrin alpha $\mathrm{v}$ immunoexpression are increased in these tumors in cats which elucidates their role in the pathogenesis of FISS.
\end{abstract}

Keywords: Injection site sarcoma, IHC, Integrin, Platelet derived growth factors

\section{INTRODUCTION}

Injection-site sarcomas previously known as vaccine-associated sarcomas were first described in 1991 by Hendrick and Goldschmidt and the development of the tumor

*Corresponding author: e-mail: msozmen@hotmail.com 
was initially attributed to the administration of vaccines (especially rabies) having aluminum-based adjuvants [1]. However, later advancements in the literature suggest that other foreign materials injected in the subcutaneous tissue or muscles can lead to neoplastic growth following chronic inflammation [2]. Though most of the injection site sarcomas are fibrosarcomas other tumors like malignant fibrous histiocytoma, osteosarcoma, rhabdomyosarcoma, chondrosarcoma, and liposarcoma have also been observed by some authors [3-5]. The predilection sites for FISS are the neck, thorax, lumbar, flank region, and limbs [6]. The risk for tumor development increases with the number of injections at the same site [7]. Various drugs especially long-acting penicillin and methylprednisolone acetate [8], lufenuron an insecticide used for flea control in animals [9], suture material [10], and microchip implants [11] have also been mentioned as risk factors for sarcoma development in cats. Most of the tumors develop between 1-3 years post-injection but may be detectable as early as 3 months and as late as 13-15 years [12,13]. Injection site sarcomas in the younger cats are more aggressive and are usually located in the subcutis and have peripheral infiltration of lymphocytes. Most of these have the myofibroblastic immunophenotype. Chronic inflammation is believed to play a significant role in the pathogenesis of these FISS by DNA damage, cellular transformation, and clonal expansion [14]. Expression of matrix metalloproteinases including membrane-type matrix metalloproteinases in the FISS indicates the role of inflammation in the pathogenies of these tumors [15].

PDGF expression has been implicated in the development of soft tissue sarcomas in humans [16] and animals [17]. PDGFR- $\beta$ expression was observed in FISS cell lines, non-injection site associated feline fibrosarcoma cell lines, feline fibroblast-derived cells line, and an in vivo tumor model exhibited expression of PDGF-BB can protect tumor cells from apoptosis induced by serum starvation or doxorubicin $[18,19]$. In human non-GIST soft tissue sarcomas, the PDGFR- $\alpha$ expression is correlated with malignancy grade i.e. grade 3 tumors have higher expression compared with grade 1 tumors and PDGFR- $\beta$ has higher positivity in patients with metastasis compared with non-metastatic patients [20].

Integrins are heterodimeric transmembrane proteins composed of non-covalently attached $\alpha$ and $\beta$ subunits and function as to mediate cell to cell and cell to extracellular matrix adhesions [21]. There exist $18 \alpha$ and $8 \beta$ subunits whose combinations can generate 24 different receptors having a different affinity and tissue distribution [2123]. Integrin subunit alpha $\mathrm{v}$ promotes cell division, and interaction amongst neoplastic cells and with extracellular matrix. It contributes in the degradation of extracellular matrix by tumors cell and supports their migration within their local environment [24]. Consequently, alpha v integrin up-regulation at the surface of neoplastic cells is frequently associated with local invasion and metastatic dissemination of cancers $[25,26]$. 
Literature is scarce about the role of PDGFA, PDGFR- $\alpha$, and integrin subunit alpha $\mathrm{v}$ in FISS. The current research highlights the clinicopathological features of FISS and immunohistochemical expression of the aforementioned molecules.

\section{MATERIALS AND METHODS}

A retrospective analysis of feline mesenchymal tumors submitted (2004-2017) to the Department of Veterinary Pathology, Faculty of Veterinary Medicine, Ondokuz Mayis University Samsun, Turkey, was performed and a total of 14 feline soft tissue sarcoma cases were shortlisted for further examination. Formalin-fixed paraffin-embedded blocks were sectioned into $5 \mu \mathrm{m}$ thick slices using a microtome. Sections were deparaffinized as per standard histological procedure and stained with hematoxylin and eosin. The diagnosis of the tumors was reviewed after histological analysis and subsequent immunolabelling. Histological grading of the tumors was done by following the criteria described for soft tissue sarcomas by Federation Nationale des Centers de Lutte Contre le Cancer (FNCLCC) for humans, but is also widely accepted in animal oncology $[25,26]$. The tumors were graded based on the mitotic rate, presence or absence of necrosis, and degree of differentiation (Table 1). Mitotic count was determined in an area of $2.37 \mathrm{~mm} 2$ at $40 \mathrm{x}$ (10 high power field) by using a microscope assembled with an ocular of field number (FN) $22 \mathrm{~mm}$ [27].

Table 1. Criteria used for grading soft tissue sarcomas

\begin{tabular}{|ll}
\hline Degree of Differentiation & $\begin{array}{l}\text { Score 1: Tumor cells are well differentiated and show high resemblance to } \\
\text { adult mesenchymal tissue e.g. well-differentiated liposarcoma }\end{array}$ \\
& $\begin{array}{l}\text { Score 2: Sarcomas for which histologic type is certain e.g. myxoid } \\
\text { liposarcoma } \\
\text { Score 3: Embryonal and poorly differentiated sarcoma }\end{array}$ \\
& Score 1: 0-9 mitotic figures in an area of $2.37 \mathrm{~mm}^{2}$ \\
Mitotic Count: & Score 2: 10-19 mitotic figures in an area of $2.37 \mathrm{~mm}^{2}$ \\
& Score 3: more than 20 mitotic figures in an area of $2.37 \mathrm{~mm}^{2}$ \\
Tumor necrosis: & Score 0: No necrosis \\
& Score 1: Less than 50\% of tumor has necrosis \\
& Score 2: More than $50 \%$ of tumor has necrosis \\
Histological grade: & Grade 1: Total score 2, 3 \\
Grade 2: Total score 4,5 & Grade 3: Total score $6,7,8$ \\
\hline
\end{tabular}

\section{Histochemical stains}

Masson's trichrome stain and Alcian blue/Periodic acid Schiff (AB-PAS) were used for the evaluation of various stromal components of tumor tissues. Masson's trichrome staining was performed for the evaluation of collagen as described by Jones et al. [28] and was graded 1 for very mild staining of the stromal tissue, 2 for moderate, and 3 
for fair positivity. AB-PAS staining was carried out as per the method of the Mowry $[29,30]$ for the evaluation of mucopolysaccharides.

\section{Immunohistochemistry}

The formalin-fixed paraffin-embedded tissue sections were subjected to immunohistochemical staining using the streptavidin-biotin peroxidase method [31]. The details of the antibodies used are presented in Tables $2 \& 3$.

Table 2. Panel of antibodies used for histogenic characterization of tumors

\begin{tabular}{|c|c|c|c|}
\hline Antibody & Dilution & Host/isotype/immunogen & Source $\&$ product codes \\
\hline Myoglobin & $1: 10000$ & Rabbit, PAb*, IgG, Human & Abcam, ab74213 \\
\hline $\begin{array}{l}\text { Alpha sarcomeric } \\
\text { actinin }\end{array}$ & $1: 10000$ & Mouse, MAb†, IgG1, rabbit & Sigma Aldrich, A7811 \\
\hline $\begin{array}{l}\text { Alpha smooth } \\
\text { muscle actin }\end{array}$ & $1: 10000$ & Mouse, MAb, IgG2akappa & Thermo, MS-113-P \\
\hline Desmin & $1: 10000$ & Mouse, MAb, IgG2b, Chicken & Santa-Cruz, sc-23879 \\
\hline Myogenin & $1: 50$ & Mouse, MAb, IgG1 Kappa & MGN185(F5D), NBP2-29431 \\
\hline MyoD1 & $1: 50$ & Mouse, MAb, IgG1 Kappa & $\begin{array}{l}\text { NB100-56511, Novus } \\
\text { Biologicals }\end{array}$ \\
\hline $\begin{array}{l}\text { Muscle specific } \\
\text { actin }\end{array}$ & Ready to use & Mouse, Mab, IgG1 kappa & Neomakers, Ab-4, MS-742-R7 \\
\hline Vimentin & $1: 10000$ & Mouse, MAb, IgG2a, Bovine & Abcam, ab28028 \\
\hline S-100 & $1: 10000$ & Mouse, MAb, IgG2a, Bovine & Thermo, MS-296-P \\
\hline GFAP & $1: 4000$ & Mouse, MAb, IgG1 & Merck Millipore, MAB3402 \\
\hline
\end{tabular}

*PAb; Polyclonal antibody, †Mab; Monoclonal Antibody

Table 3. Details of the antibodies used to study the immunoexpression of PDGFA, PDGFR- $\alpha$, and integrin alpha $\mathrm{v}$

\begin{tabular}{cccc}
\hline Antibody & Dilution & Host/Isotype/Immunogen & Source \& Product codes \\
\hline Integrin alpha $v$ & $1: 500$ & Rabbit, PAb*, IgG, & Merck: AB1930 \\
PDGFA & $1: 100$ & Mouse, MAb†, IgG1 & Santa Cruz (E-10): sc-9974 \\
PDGFR- $\alpha$ & $1: 400$ & Rabbit, PAb, IgG, & Santa Cruz (C-20): sc-338 \\
\hline
\end{tabular}

*PAb; Polyclonal antibody, †MAb; Monoclonal antibody

Briefly, the serial sections were rinsed with distilled water after processing in xylene and graded levels of alcohol. Following this, a 3\% solution of hydrogen peroxide in absolute methanol was used to block the activity of endogenous peroxidase for 10 minutes. After rinsing with phosphate-buffered saline (PBS, pH 7.4), the tissue sections were subjected to antigen retrieval using citrate buffer ( $\mathrm{pH}$ 6.0) in a microwave oven $(600 \mathrm{~W})$ for $10 \mathrm{~min}$. A ready to use commercially available blocking solution 
(Zymed Laboratories, Inc.; San Francisco, CA, USA) was used for 10 minutes (at room temperature) to block nonspecific binding of the secondary antibody. Sections were washed with PBS and then incubated with each of the primary antibodies for 1-2 hours at room temperature. A brief rinsing of sections with PBS 2-3 times was followed by incubation with a biotin-conjugated secondary antibody for 20 minutes at room temperature (Zymed Laboratories). Later, sections were washed with PBS and treated with streptavidin-biotin-peroxidase complex (SABC, Zymed Laboratories) for 20 minutes at room temperature in a humidifying chamber. After brief rinsing with PBS signals were visualized using 3-amino-9-ethylcarbazole (AEC substrate kit; Invitrogen, Camarillo, Canada) as a chromogen. A counterstaining with Harris hematoxylin was performed for 1 minute, rinsed with running tap water, and mounted with an aqueous mounting medium (Vision Mount; Lab Vision, USA). Primary antibodies were omitted from negative control sections, which were incubated with either PBS or diluted normal serum from the species in which the primary antibody was raised.

\section{Evaluation of immunostaining}

A semiquantitative approach was used to evaluate the immunolabeling of various antibodies. The percentage of the positive cells and intensity of staining were taken into consideration during the evaluation and a score between 0-300 was given depending on both factors. H-score (Histological score) was calculated by the formula 1x (\% cells weak positive), $+2 \mathrm{x}$ ( $\%$ cells moderately positive $),+3 \mathrm{x}$ ( $\%$ cells strong positive).

\section{Statistical analysis}

GraphPad Prism ${ }^{\circledR} 5$ was used for the statistical analyses of the data. Mitotic count between tumor grades were compared by Mann-Whitney test. The data (H-score) obtained from the immunohistochemical analysis of different grades of tumors was analyzed by descriptive statistics and also compared for the difference in their median values by using the Kruskal Wallis test. $\mathrm{P}<0.05$ was considered significant.

Informed consent: Informed consent has been obtained for client-owned animals included in this study.

\section{RESULTS}

\section{Clinicopathological findings}

The majority of the tumors were fibrosarcomas ( $n=13 / 14)$, except for one case of myxoid liposarcoma (Table 4). The tumors included in this study occurred at the sites commonly used for injections or vaccine administration. No information was available about the use of any vaccine or drug. The age range of the cats varied from five to 13 years (median 9.5 years). Seven of the cats were male and five were female while gender information was missing about two cats. 
Table 4. Clinical and histopathological characteristics of tumors in 14 cats

\begin{tabular}{ccclcccc}
\hline No. $\begin{array}{c}\text { Age } \\
(\mathbf{Y})\end{array}$ & Sex & Tumor Site & Diagnosis & Mitosis* & Necrosis & $\begin{array}{c}\text { Differen- } \\
\text { tiationt }\end{array}$ & $\begin{array}{c}\text { Tumor } \\
\text { Grade }\end{array}$ \\
\hline 9 & M & Interscapular & Fibrosarcoma & 1 & 2 & 2 & 2 \\
NA & NA & Interscapular & Fibrosarcoma & 2 & 1 & 1 & 2 \\
5 & M & Back/Dorsum & Fibrosarcoma & 1 & 2 & 2 & 2 \\
10 & M & Right gluteal & Fibrosarcoma & 1 & 2 & 1 & 2 \\
11 & F & Left thoracic & Fibrosarcoma & 2 & 1 & 2 & 2 \\
9 & M & Back/Dorsum & Fibrosarcoma & 1 & 1 & 2 & 2 \\
NA & NA & Dorsolumbar & Fibrosarcoma & 1 & 1 & 2 & 2 \\
13 & M & Interscapular & Liposarcoma & 2 & 1 & 2 & 2 \\
12 & F & Dorsal region & Fibrosarcoma & 2 & 1 & 2 & 2 \\
10 & M & Scapular region & Fibrosarcoma & 2 & 1 & 2 & 2 \\
12 & F & Interscapular & Fibrosarcoma & 3 & 2 & 2 & 3 \\
6.5 & M & Left thoracic & Fibrosarcoma & 3 & 2 & 2 & 3 \\
9 & F & Left thoracic wall & Fibrosarcoma & 3 & 1 & 2 & 3 \\
\hline 8 & F & Subcutaneous & Fibrosarcoma & 3 & 1 & 3 & 3 \\
\hline
\end{tabular}

M: Male, F: Female, NA: Not available, ${ }^{*}$ Mitotic count was determined in an area of $2.37 \mathrm{~mm}^{2}$ at high-power field (40x objective); low (1) $=0-9$, moderate $(2)=10-19$ or high $(3)=>20{ }^{\dagger}{ }^{\dagger}(1)$ well differentiated, (2) moderately differentiated, (3) poorly differentiated

The tumors were located beneath the dermis. A pseudocapsule was observed in a few cases. Peripheral foci of lymphocytic infiltration were noticed (Figure 1a). However, histiocytic cells or macrophages were scant in the cases studied (observed in three cases). The tumor cells were comprised of mesenchymal spindle-shaped cells. Most of the tumors had anaplastic features with the presence of multinucleated cells while classical herringbone pattern was rarely observed (Figure 1b, 1c). Variably sized areas of necrosis were also present (Figure 1a). Mitotic index was significantly higher in grade 3 tumors in comparison with grade 2 tumors $(\mathrm{P}<0.05)$.

Mucin containing areas were observed in some of the tumors. The myxoid liposarcoma was composed of cells with a peripheral nucleus having a vacuolar cytoplasm (Figure 2). Neoplastic cells exhibited marked anisocytosis and anisokaryosis. Many giant cells were scattered through the tumor stroma. Staining with AB-PAS showed mucin secretion in the myxoid areas leading to the diagnosis of myxoid liposarcoma (Figure 3).

\section{Histochemical analysis of tumors}

Myxoid or mucinous areas stained positive in 8/14 tumors with AB-PAS staining while $12 / 14$ tumors showed mild to fair staining of the stromal collagen with trichrome 
stain, four tumors in each category i.e. 1, 2, and 3, and two tumors were negative (Table 5).
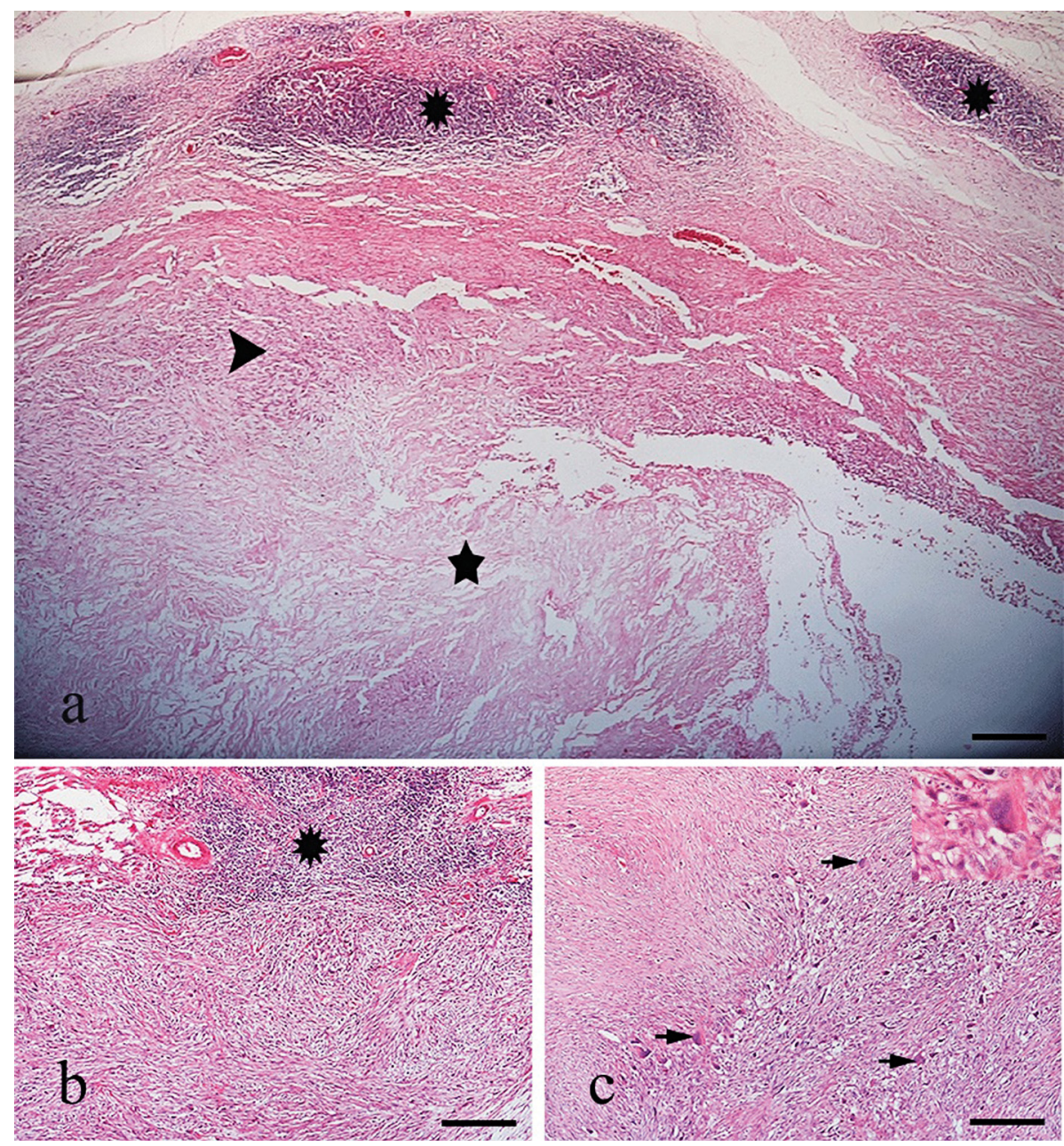

Figure 1. a: Photomicrograph of an injection site fibrosarcoma from a cat. Note the peripheral foci of inflammatory cells (asterisks), tumor cells (arrowhead), and necrotic areas (star), b: A grade 2 fibrosarcoma with peripheral lymphocytic infiltration (asterisk). c: A highly anaplastic grade 3 fibrosarcoma with many multinucleated tumor giant cells (arrows) inset: high magnification view of tumor giant cell. H\&E. Bar, a, $300 \mu \mathrm{m}$; b \& c, $150 \mu \mathrm{m}$.

\section{Immunohistochemical staining}

Vimentin reactivity was observed in all the tumors (Figure 4). Four tumors showed smooth muscle actin positivity at the periphery and two for muscle actin. A focal area of mild myoglobin reactivity was noticed in one case (tumor no: 12) which was 
categorized as injection-site sarcoma. GFAP, S100, desmin, muscle actin, sarcomeric actin, myoglobin, myogenin, and myoD1 were negative.

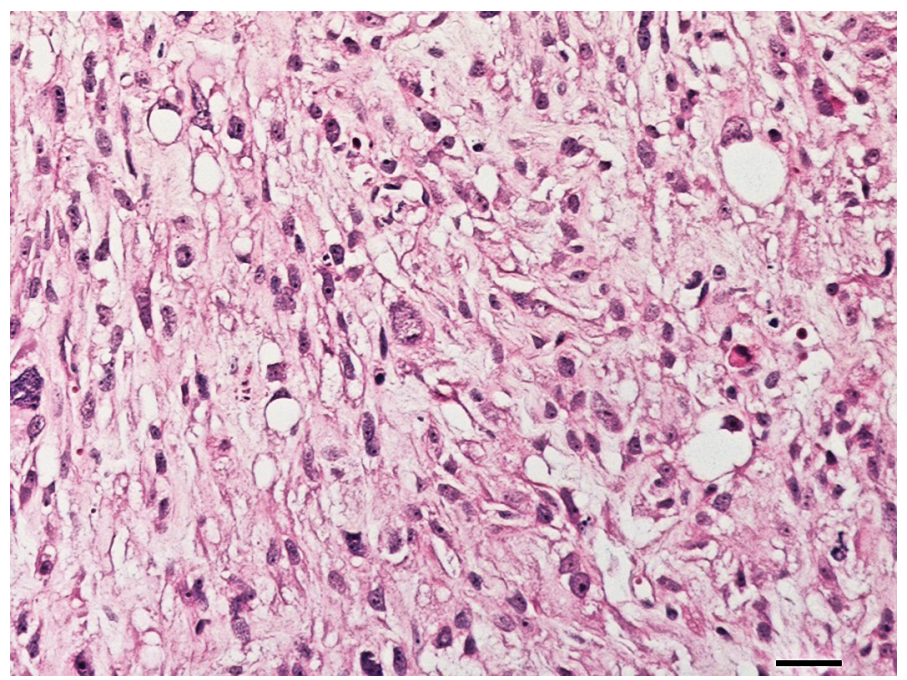

Figure 2. Photomicrograph of a myxoid liposarcoma showing neoplastic cells with cytoplasmic vacuolation pushing the nucleus to the periphery of the cell. H\&E. Bar,30 $\mu \mathrm{m}$.

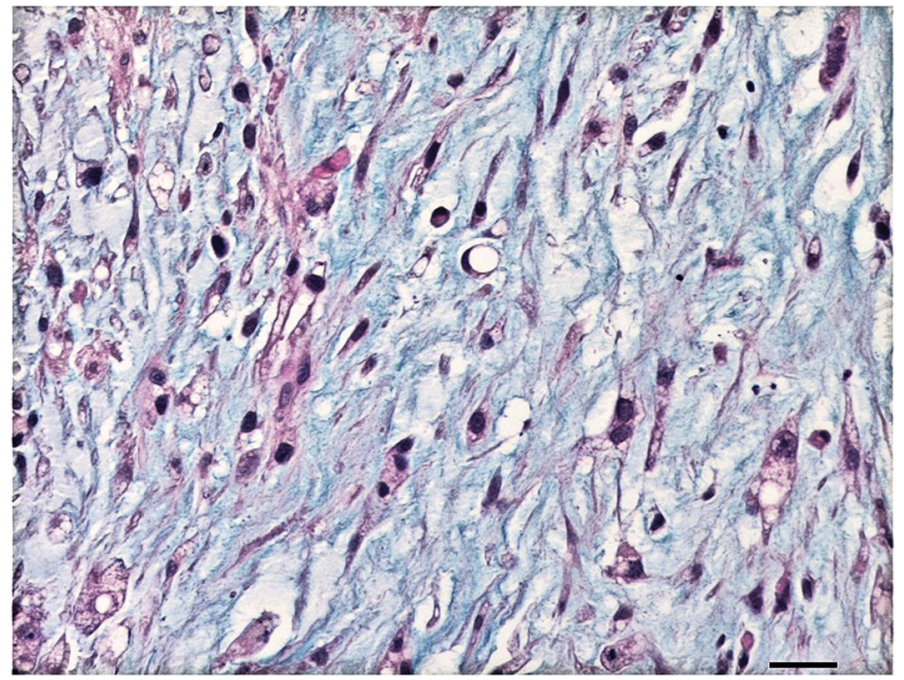

Figure 3. AB-PAS staining of myxoid liposarcoma showing mucinous matrix. Bar,30 $\mu \mathrm{m}$. 


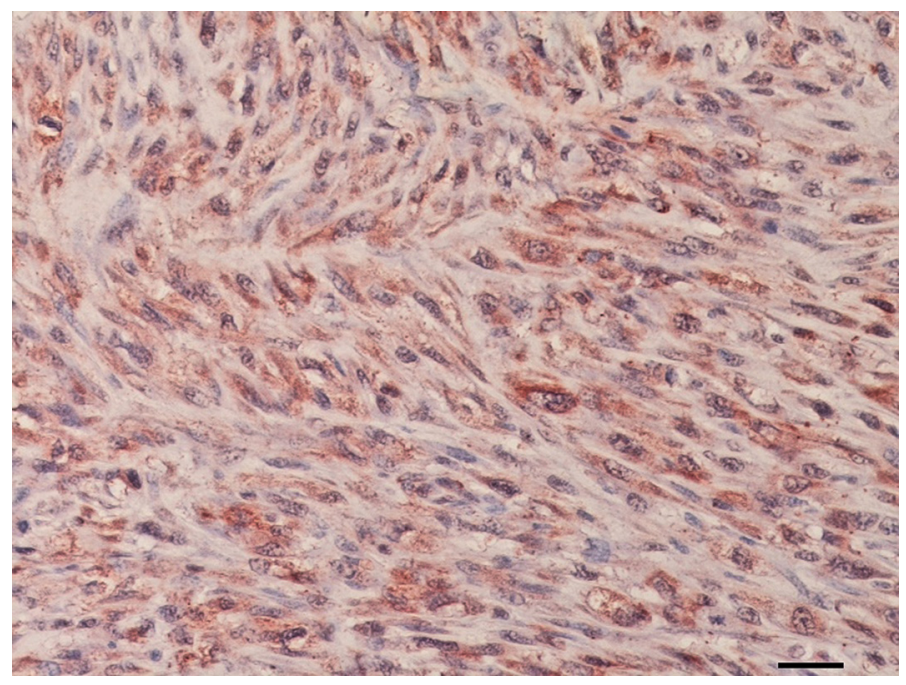

Figure 4. Cytoplasmic immunoreactivity for the vimentin antibody from an injection-site fibrosarcoma of a cat. IHC. Bar,30 $\mu \mathrm{m}$.

Table 5. Histochemical characteristics of tumors in 14 cats

\begin{tabular}{cccc}
\hline $\begin{array}{c}\text { Tumor } \\
\text { No }\end{array}$ & Diagnosis & AB-PAS & Trichrome* \\
& Fibrosarcoma & Positive & + \\
& Fibrosarcoma & Positive & ++ \\
& Fibrosarcoma & Positive & + \\
& Fibrosarcoma & Positive & ++ \\
& Fibrosarcoma & Positive & +++ \\
\hline Fibrosarcoma & Negative & +++ \\
& Fibrosarcoma & Positive & + \\
Myxoid Liposarcoma & Positive & +++ \\
Fibrosarcoma & Negative & - \\
\hline Fibrosarcoma & Negative & - \\
Fibrosarcoma & Negative & +++ \\
Fibrosarcoma & Positive & + \\
Fibrosarcoma & Negative & ++ \\
Fibrosarcoma & Negative & ++ \\
\hline
\end{tabular}

*Trichrome staining: + (Very low amount of collagenous stroma), ++ (Mild to moderate collagenous stroma), +++ (Fair amount of collagenous stroma). 


\section{PDGFA and PDGFR- $\alpha$}

Cytoplasmic PDGFA expression was noticed in neoplastic cells in all the tumors (Figure 5). Other than tumor cells, remnants of muscle cells, blood vessel walls, and epithelium of hair follicles showed positive reactivity for PDGFA. Histiocytic cells with cytoplasmic immunoreactivity were noticed in a few cases. Though grade 3 tumors showed relatively higher PDGFA expression than grade 2 tumors, statistically this difference was non-significant.

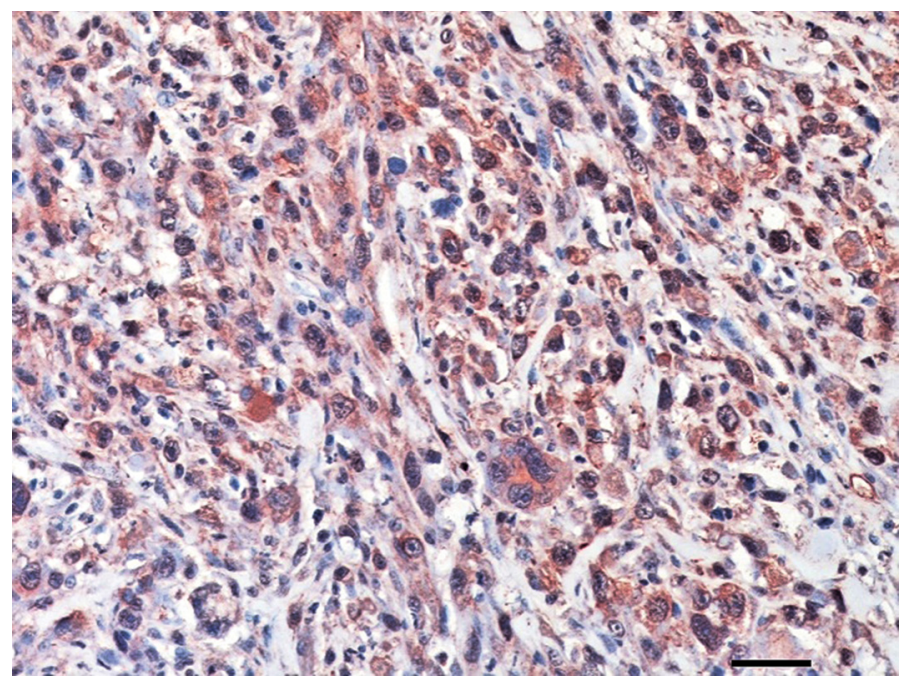

Figure 5. PDGFA immunoreactivity in an injection-site fibrosarcoma of a cat. IHC. Bar, $30 \mu \mathrm{m}$.

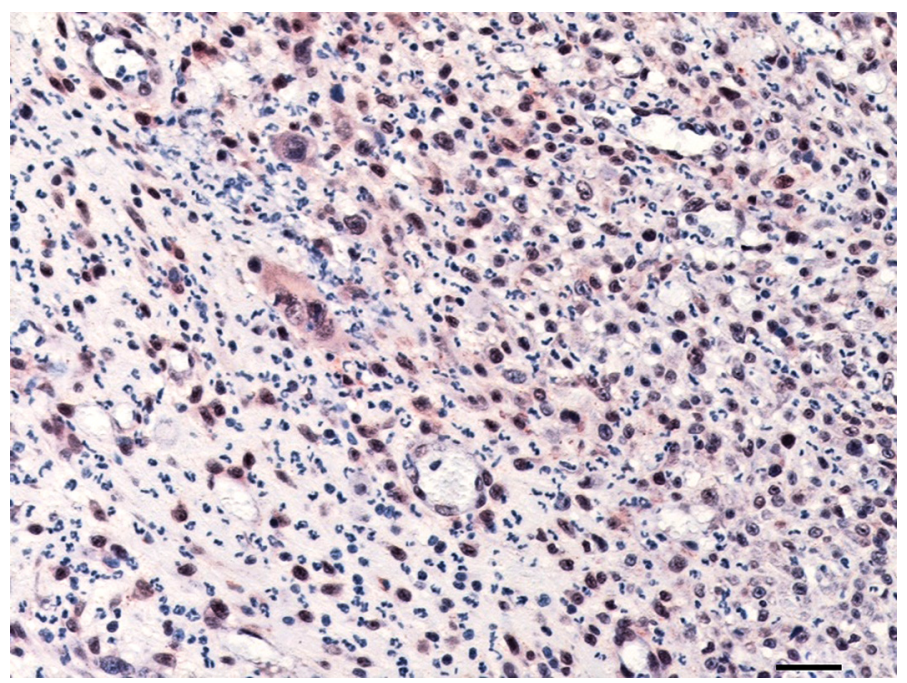

Figure 6. Neoplastic cells of a feline injection-site sarcoma showing nuclear and cytoplasmic staining for PDGFR- $\alpha$. IHC. Bar, $30 \mu \mathrm{m}$. 
PDGFR- $\alpha$ expression was observed in 14/14 tumors (Figure 6). Tumor cells showed both nuclear and cytoplasmic staining for PDGFR- $\alpha$. A variable staining reaction was observed in peripheral lymphocytes and macrophages for PDGFR- $\alpha$. Other than tumor cells, blood vessels and muscles were also positive for PDGFR- $\alpha$. Numerical scoring of PDGFR- $\alpha$ expression was relatively high in grade 2 tumors in comparison with grade 3 tumors, however, there was no statistically significant difference. The semiquantitative analysis of immunoreactivity score is given in Table 6 .

Table 6. Comparison of $\mathrm{H}$-score of Integrin alpha v, PDGFA, and PDGFR-alpha in feline fibrosarcoma

\begin{tabular}{cccc}
\hline Tumor Grade & Integrin alpha v & PDGFA & PDGFR \\
\hline 2 & $88.33 \pm 18.31$ & $108.4 \pm 24.91$ & $121.4 \pm 19.95$ \\
3 & $112.5 \pm 33.82$ & $140.0 \pm 24.15$ & $78.25 \pm 29.01$ \\
\hline
\end{tabular}

Data presented as Mean \pm SEM, $\mathrm{p}>0.05, \mathrm{H}$-score did not show any significant difference between different grades of tumors in cats

\section{Integrin alpha $\mathbf{v}$}

Membranous, as well as cytoplasmic staining was observed in most of the tumors $(n=13 / 14)$ as shown in Figure 7. Multinucleated tumor giant cells and normal skeletal muscle cells also showed cytoplasmic reactivity for the integrin alpha v. However, infiltrating lymphocytic foci were negatively stained. Neoplastic cells in grade 3 FISS revealed a higher immunoreactivity than grade 2 tumors, however, statistically, this difference was not significant. The mean score of the immunoreactivity of integrin alpha $\mathrm{v}$ is presented in Table 6.

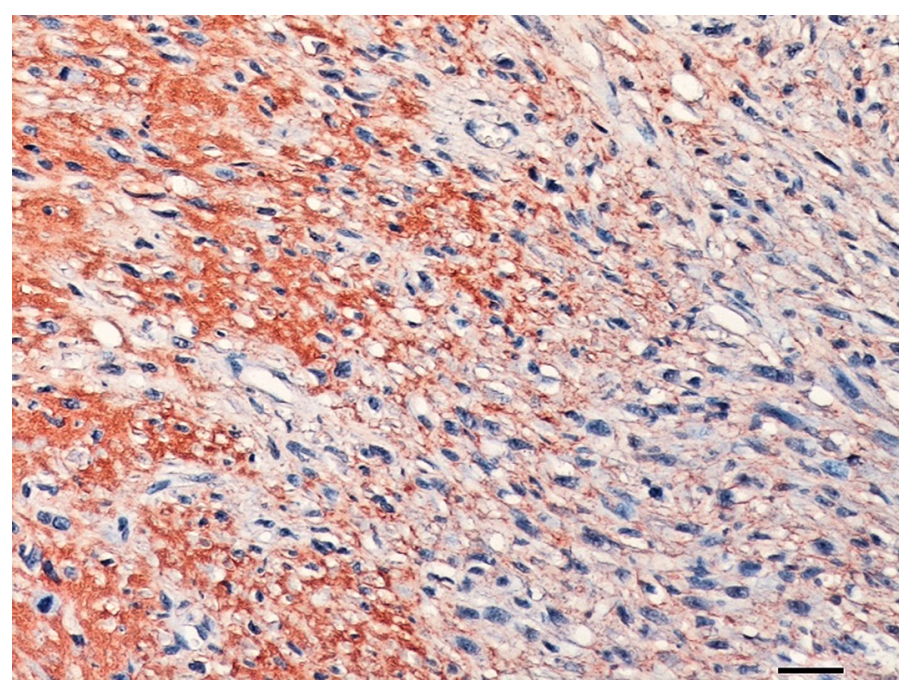

Figure 7. Integrin alpha $\mathrm{v}$ expression in a grade 3 injection-site fibrosarcoma of a cat. IHC. Bar, $30 \mu \mathrm{m}$. 


\section{DISCUSSION}

Injection-site sarcomas are believed to originate in response to the injection of foreign materials in any animal species especially cats. In the current study, 13 cases of fibrosarcomas and one myxosarcoma were observed at the anatomical sites used for injections or vaccine administration in cats. As observed in the current study fibrosarcoma is the most common histological variant occurring at the injection sites in cats, although reports of other tumors e.g. chondrosarcoma, rhabdomyosarcoma, osteosarcoma, and liposarcoma do exist $[3,4,32]$. Generally, injection site fibrosarcoma is of moderate to high-grade invasive tumors [33,34]. We observed grade $2(n=10)$ and grade $3(n=4)$ tumors in cats and it was in partial agreement with Couto et al. [35], who reported a higher number of grade $2(47.7 \%)$ and grade $3(27.3 \%)$ fibrosarcomas along with $25 \%$ grade 1 tumors.

Histological examination of the tumors revealed a subcutaneous location of tumors with peripheral lymphocytic infiltration and few histiocytes. This feature has been consistently observed since the very first reports of the injection site sarcomas and is considered pathognomonic for diagnosis [3,7,32,33,36,37]. Previous studies also reported the presence of macrophages with engulfed foreign material (aluminumbased adjuvant used in the vaccine), but it was not a predominant feature in our study. But it is not a mandatory feature of all the FISS as Couto et al. [35] observed large foamy macrophages in only $22.5 \%$ and $25 \%$ of primary and recurrent fibrosarcomas, respectively. Moreover, there have been reports of feline fibrosarcomas at the presumed injection site with inflammatory reaction without foamy macrophages [34,38,39]. The presence or absence of the macrophages with intracytoplasmic basophilic granular material may be related to the presence or absence of adjuvants in the vaccine [34]. The persistence of inflammatory cells is a major factor contributing to the pathogenesis of injection-site sarcomas [14,40,41].

Tumor cells were pleomorphic to spindle-shaped with a lack of characteristic herringbone pattern of fibrosarcomas. Multinucleated giant cells are another histological characteristic of FISS [34,35] which were also recorded in the present study. Tumor samples from eight cats demonstrated myxomatous/ mucin containing areas with loosely arranged spindle-shaped or stellate cells. Injection site sarcomas with myxomatous matrix were also observed in previous studies and injection site sarcomas have a greater tendency to produce myxomatous stroma as compared to non-injection site feline sarcomas $[37,42]$. As observed in previous studies, mitotic count was significantly high in grade 3 tumors as compared to grade 2 tumors. High mitotic rate indicates rapid proliferation of neoplastic cells and therefore is a feature of fast growing aggressive tumors $[39,43]$.

All the tumors in this study showed no reactivity for desmin and were positive for vimentin. This finding is in agreement with the previous studies [35]. One sample of cats showed reactivity to muscle actin and alpha-smooth muscle reactivity was noticed in 4/14 tumors of cats. This number is quite low as compared to previous 
studies (28/44) [35], (7/10) [34]. Smooth muscle reactivity indicates the presence of myofibroblasts in the tumors which are considered a transitory phase through which fibroblasts and macrophages pass during wound healing [2]. Though their precise role in ISSs is unclear[44], some authors describe it as an atypical response to traumatic injury [2].

Desmin, S-100, sarcomeric actinin, pan-cytokeratin, GFAP, myogenin, and myoD1 were negative in the current study. One case showed focal reactivity to myoglobin and two for muscle actin. Previously, S-100 positivity was observed in a chondrosarcoma at the injection site but not in fibrosarcoma [3]. Myoglobin reactivity in one animal in the current study may indicate regenerating muscle cells in the areas invaded by tumor cells. Myogenin and myoD1 are highly specific and sensitive markers for tumors showing skeletal muscle differentiation [45]. Negative reactions to these antibodies in all feline tumors helped in the exclusion of rhabdomyosarcomatous differentiation in the tumors under study.

PDGF/PDGFRs axis plays an important role in the pathogenesis of many humans and animal tumors including soft tissue sarcomas[17]. Upregulation of PDGFA and its receptor alpha was present in all the $(100 \%)$ tumors. Other than tumor cells, muscle cells, blood vessel walls and epithelium of hair follicles showed positive reactivity. The results of the current study are partially in line with the previous reports of the immunoreactivity of PDGF and its cognate receptor in feline injection-site sarcomas [46]. Hendrick [46] also reported the immunopositivity of peripheral lymphocytes and macrophages and strong staining in the tumor cells near these inflammatory cells which were partially observed in the current study. The difference may be due to the use of antibodies against a different isoform of PDGF and PDGFR. The two other studies investigating the role of PDGF/PDGFRs axis in FISS were carried out targeting PDGF-BB and PDGFR- $\beta$ but not $\alpha[18,19]$. They used FISS cell lines and a xenograft murine tumor model and evaluated imatinib [18] and masitinib [19] anti-tyrosine kinase drugs to inhibit tumor cell growth by blocking the expression of PDGFR- $\beta$. However, in human medicine, co-expression of PDGFR- $\alpha$ and its ligands has been implicated in several tumors and an anti-PDGFR- $\alpha$ antibody named olaratumab is being evaluated as a therapeutic candidate [47]. The PDGFA and PDGFR- $\alpha$ expression was not significantly different between grade 2 and grade 3 tumors. Literature is scarce about correlation between histological grades and PDGFA/PDGFR- $\alpha$ expression in FISS. PDGFA/PDGFR- $\alpha$ expression may vary amongst different histological grades and types of tumors. A positive correlation between histological grades, proliferative index and PDGFA/PDGFR- $\alpha$ expression was observed in soft tissue sarcomas in humans[20] while oligodendrogliomas and meningiomas only showed this correlation for PDGFA and not for PDGFR- $\alpha$ expression [48,49].

Integrin alpha $\mathrm{v}$ binds to vitronectin and fibronectin which are its principal ligands and contribute to local invasion and distant spread of the neoplastic cells [50]. The role of integrin alpha $\mathrm{v}$ is well established in several human cancers e.g. melanoma, breast, and pancreatic tumors [51-53]. Integrin alpha $\mathrm{v}$ expression was observed in $93 \%$ of the 
tumor samples. Literature is scarce on the role of integrin alpha $\mathrm{v}$ expression in FISS and we find only one previous report describing the expression of integrin alpha $\mathrm{v} \beta 3$ in the tumors that authors described as "highly infiltrative spontaneous fibrosarcomas". The main objective of the study was to test a NIR-dye labeled nanoprobe targeting the integrin alpha v $\beta 3$ in the near-infrared optical guided excision of the tumors. They observed integrin expression on the endothelial cells and the surface of the tumor cells in the proximity of the blood vessels[54]. Our results are in partial agreement with the findings of the aforementioned study. However, it is not clear whether the enrolled subjects in the previous study were having spontaneous fibrosarcoma or injection-site fibrosarcoma as the pathogenesis of both is different. Furthermore, the authors described the positive staining in the vascular endothelium and tumor cells in the vicinity of the vessels, but we observed a widespread staining reaction throughout the tumor tissue, including multinucleated tumor cells, and normal skeletal muscles. A high immunoexpression was observed in grade 3 tumors as compared to grade 2 tumors. Similar findings have been reported in human gliomas [55]

In conclusion, the FISS continues to be an important malignancy in cats and fibrosarcoma is the predominant histological phenotype in cats. PDGFA, PDGFR- $\alpha$, integrin alpha $\mathrm{v}$ immunoexpression is considerably increased in FISS. This explains the possible role of these molecules in the pathogenesis of FISS. However, further studies involving large cohorts of animals and focusing on other adhesion molecules, growth factors, and angiogenic factors may help in a better understanding of tumor progression and identification of a precise target for chemotherapy.

\section{Acknowledgment}

The author (Ishtiaq Ahmed) is thankful to the Turkish Scientific and Technological Research Council (Tubitak) Turkey for providing scholarship for doctoral study and the University of Veterinary \& Animal Sciences Lahore Pakistan for granting study leave. The current research was carried out as a part of Ph.D. dissertation at the Department of Pathology, Faculty of Veterinary Medicine, Ondokuz Mayis University, Samsun, Turkey.

\section{Authors' contributions}

IA designed and executed the study, drafted the manuscript. MS participated in the design, of the study, supervised the research, performed the statistical analysis and revised the draft the manuscript. All authors read and approved the final manuscript.

\section{Declaration of conflicting interests}

The author(s) declared no potential conflicts of interest with respect to the research, authorship, and/or publication of this article. 


\section{Funding}

This research received no external funding.

\section{REFERENCES}

1. Zabielska-Koczywas K,Wojtalewicz A,Lechowski R: Current knowledge on feline injectionsite sarcoma treatment. Acta Vet. Scand. 2017, 59: 47, doi:10.1186/s13028-017-0315-y.

2. Martano M,Morello E,Buracco P: Feline injection-site sarcoma: Past, present and future perspectives. Vet. J. 2011, 188: 136-141, doi:https://doi.org/10.1016/j.tvjl.2010.04.025.

3. Hendrick M,Brooks J: Postvaccinal sarcomas in the cat: Histology and immunohistochemistry. Vet. Pathol. 1994, 31: 126-129.

4. Esplin D,Jaffe M,McGill L: Metastasizing liposarcoma associated with a vaccination site in a cat. Feline practice 1996:20-23.

5. Chang HW,Ho SY,Lo HF,Tu YC,Jeng CR,Liu CH,Wang FI,Pang VF: Vaccine-associated rhabdomyosarcoma with spinal epidural invasion and pulmonary metastasis in a cat. Vet. Pathol. 2006, 43: 55-58, doi:10.1354/vp.43-1-55.

6. Hendrick MJ. Mesenchymal tumors of the skin and soft tissues. In Tumors in domestic animals, John Wiley \& Sons, Inc.: 2016; 10.1002/9781119181200.ch5pp. 142-175.

7. Kass PH,Barnes WG, Jr.,Spangler WL,Chomel BB,Culbertson MR: Epidemiologic evidence for a causal relation between vaccination and fibrosarcoma tumorigenesis in cats. J. Am. Vet. Med. Assoc. 1993, 203: 396-405.

8. Kass PH,Spangler WL,Hendrick MJ,McGill LD,Esplin DG,Lester S,Slater M,Meyer EK,Boucher F,Peters EM: Multicenter case-control study of risk factors associated with development of vaccine-associated sarcomas in cats. J. Am. Vet. Med. Assoc. 2003, 223: 1283-1292.

9. Esplin D,Bigelow M,McGill L,Wilson S: Fibrosarcoma at the site of a lufenuron injection in a cat. Vet. Cancer Soc. Newsletter 1999, 23: 8-9.

10. Buracco P,Martano M,Morello E,Ratto A: Vaccine-associated-like fibrosarcoma at the site of a deep nonabsorbable suture in a cat. Vet. J. 2002, 163: 105-107, doi:10.1053/ tvj1.2001.0617.

11. Daly MK,Saba CF,Crochik SS,Howerth EW,Kosarek CE,Cornell KK,Roberts RE,Northrup NC: Fibrosarcoma adjacent to the site of microchip implantation in a cat. J. Feline Med. Surg. 2008, 10: 202-205, doi:https://doi.org/10.1016/j.jfms.2007.10.011.

12. McEntee MC,Page RL: Feline vaccine-associated sarcomas. J. Vet. Intern. Med. 2001, 15: 176-182.

13. Wilcock B,Wilcock A,Bottoms K: Feline postvaccinal sarcoma: 20 years later. The Can. Vet. J. 2012, 53: 430-434.

14. Woodward KN: Origins of injection-site sarcomas in cats: The possible role of chronic inflammation—a review. ISRN Vet. Sci. 2011, 2011: 210982, doi:10.5402/2011/210982.

15. Sorensen KC,Kitchell BE,Schaeffer DJ,Mardis PE: Expression of matrix metalloproteinases in feline vaccine site-associated sarcomas. Am. J. Vet. Res. 2004, 65: 373-379.

16. Malhotra B,Schuetze SM: Dermatofibrosarcoma protruberans treatment with plateletderived growth factor receptor inhibitor: A review of clinical trial results. Curr. Opin. Oncol. 2012, 24: 419-424, doi:10.1097/CCO.0b013e328353d78d. 
17. Jacobs TM,Poehlmann CE,Kiupel M: Injection-site sarcoma in a dog: Clinical and pathological findings. Case Rep. Vet. Med. 2017, 2017: 4, doi:10.1155/2017/6952634.

18. Katayama R,Huelsmeyer MK,Marr AK,Kurzman ID,Thamm DH,Vail DM: Imatinib mesylate inhibits platelet-derived growth factor activity and increases chemosensitivity in feline vaccine-associated sarcoma. Cancer Chemother Pharmacol 2004, 54: 25-33, doi:10.1007/s00280-004-0780-7.

19. Lawrence J,Saba C,Gogal R,Lamberth O,Vandenplas ML,Hurley DJ,Dubreuil P,Hermine O,Dobbin K,Turek M: Masitinib demonstrates anti-proliferative and pro-apoptotic activity in primary and metastatic feline injection-site sarcoma cells*. Vet. Comp. Oncol. 2012, 10: 143-154, doi:10.1111/j.1476-5829.2011.00291.x.

20. Kilvaer TK,Valkov A,Sorbye SW,Donnem T,Smeland E,Bremnes RM,Busund LT: Plateletderived growth factors in non-gist soft-tissue sarcomas identify a subgroup of patients with wide resection margins and poor disease-specific survival. Sarcoma 2010, 2010: 751304, doi:10.1155/2010/751304.

21. Hynes RO: Integrins: Bidirectional, allosteric signaling machines. Cell 2002, 110: 673-687.

22. Takada Y,Ye X,Simon S: The integrins. Genome Biol. 2007, 8: 215, doi:10.1186/gb-20078-5-215.

23. Barczyk M,Carracedo S,Gullberg D: Integrins. Cell Tissue Res. 2010, 339: 269-280, doi:10.1007/s00441-009-0834-6.

24. Silletti S,Kessler T,Goldberg J,Boger DL,Cheresh DA: Disruption of matrix metalloproteinase 2 binding to integrin alpha vbeta 3 by an organic molecule inhibits angiogenesis and tumor growth in vivo. Proc. Natl. Acad. Sci. U. S. A. 2001, 98: 119-124, doi:10.1073/pnas.011343298.

25. Dennis MM,McSporran KD,Bacon NJ,Schulman FY,Foster RA,Powers BE: Prognostic factors for cutaneous and subcutaneous soft tissue sarcomas in dogs. Vet. Pathol. 2011, 48: 73-84, doi:10.1177/0300985810388820.

26. Meuten DJ. Appendix: Diagnostic schemes and algorithms. In Tumors in domestic animals, John Wiley \& Sons, Inc.: 2016; 10.1002/9781119181200.apppp. 942-978.

27. Meuten DJ,Moore FM,George JW: Mitotic count and the field of view area: Time to standardize. Vet. Pathol. 2016, 53: 7-9, doi:10.1177/0300985815593349.

28. Jones ML,Bancroft JD,Gamble M: Connective tissues and stains. Theory and practice of histological techniques 2008, 6: 135-160.

29. Mowry RW: Alcian blue techniques for the histochemical study of acid carbohydrates. J Histochem Cytochem 1956, 4: 403-407.

30. Mowry RW: The special value of methods that color both acidic and vicinal hydroxyl groups in the histochemical study of mucins. With revised directions for the colloidal iron stain, the use of alcian blue g8x and their combinations with the periodic acid-schiff reaction*. Ann. N. Y. Acad. Sci. 1963, 106: 402-423, doi:10.1111/j.1749-6632.1963.tb16654.x.

31. Ahmed I,Sozmen M: Expression of pdgf-a, pdgfra, integrin subunit alpha $v$ and selectin $e$ is increased in canine cutaneous fibrosarcomas. Biotech. \& histochem.: 2020, 1-9, doi:10.1 080/10520295.2020.1832256.

32. Esplin D,Campbell R: Widespread metastasis of a fibrosarcoma associated with a vaccination site in a cat. Feline practice 1995, 23:13-16.

33. Hendrick MJ,Shofer FS,Goldschmidt MH,Haviland JC,Schelling SH,Engler SJ,Gliatto JM: Comparison of fibrosarcomas that developed at vaccination sites and at nonvaccination sites in cats: 239 cases (1991-1992). J. Am. Vet. Med. Assoc. 1994, 205: 1425-1429. 
34. Aberdein D,Munday JS,Dyer CB,Knight CG,French AF,Gibson IR: Comparison of the histology and immunohistochemistry of vaccination-site and non-vaccination-site sarcomas from cats in new zealand. N. Z. Vet. J. 2007, 55: 203-207, doi:10.1080/00480169.2007.367 69.

35. Couto SS,Griffey SM,Duarte PC,Madewell BR: Feline vaccine-associated fibrosarcoma: Morphologic distinctions. Vet. Pathol. 2002, 39: 33-41, doi:10.1354/vp.39-1-33.

36. Hendrick MJ,Goldschmidt MH,Shofer FS,Wang Y-Y,Somlyo AP: Postvaccinal sarcomas in the cat: Epidemiology and electron probe microanalytical identification of aluminum. Cancer Res. 1992, 52: 5391-5394.

37. Doddy FD,Glickman LT,Glickman NW,Janovitz EB: Feline fibrosarcomas at vaccination sites and non-vaccination sites. J. Comp. Pathol. 1996, 114: 165-174, doi:https://doi. org/10.1016/S0021-9975(96)80005-3.

38. Diep AN,Fleis RI: Pathology in practice. Widespread, metastatic liposarcoma and moderate, acute, diffuse centrilobular hepatic necrosis. J Am Vet Med Assoc 2012, 240: 391-393, doi:10.2460/javma.240.4.391.

39. Ahmed I, Sozmen M: Proliferating cell nuclear antigen expression in canine and feline spontaneous and injection-site fibrosarcomas. Pak. Vet. J. 2020, 40: 531-533.

40. Hendrick MJ,Goldschmidt MH: Do injection site reactions induce fibrosarcomas in cats? J. Am. Vet. Med. Assoc. 1991, 199: 968.

41. Macy DW,Hendrick MJ: The potential role of inflammation in the development of postvaccinal sarcomas in cats. Vet. Clin. North Am. Small Anim. Pract. 1996, 26: 103-109, doi:https://doi.org/10.1016/S0195-5616(96)50009-4.

42. Srivastav A,Kass PH,McGill LD,Kent MS,Farver TB: Methodologic approaches to histologically distinguishing vaccine versus nonvaccine-associated sarcomas using validated time and location vaccination histories in cats. ISRN Pathol. 2011, 2011: 6, doi:10.5402/2011/375143.

43. Porcellato I,Menchetti L,Brachelente C,Sforna M,Reginato A,Lepri E,Mechelli L: Feline injection-site sarcoma:Matrix remodeling and prognosis. Vet. Pathol. 2017, 54: 204-211, doi:10.1177/0300985816677148.

44. Madewell BR,Griffey SM,McEntee MC,Leppert VJ,Munn RJ: Feline vaccine-associated fibrosarcoma: An ultrastructural study of 20 tumors (1996-1999). Vet. Pathol. 2001, 38: 196-202, doi:10.1354/vp.38-2-196.

45. Cessna MH,Zhou H,Perkins SL,Tripp SR,Layfield L,Daines C,Coffin CM: Are myogenin and myod1 expression specific for rhabdomyosarcoma? A study of 150 cases, with emphasis on spindle cell mimics. Am. J. Surg. Pathol. 2001, 25: 1150-1157.

46. Hendrick MJ: Feline vaccine-associated sarcomas: Current studies on pathogenesis. J. Am. Vet. Med. Assoc. 1998, 213: 1425-1426.

47. Teyssonneau D,Italiano A: Olaratumab for soft tissue sarcoma. Expert Opin. Biol. Ther. 2017, 17: 1019-1025, doi:10.1080/14712598.2017.1339031.

48. Figarella-Branger D,Vagner-Capodano AM,Bouillot P,Graziani N,Gambarelli D,Devictor B,Zattara-Cannoni H,Bianco N,Grisoli F,Pellissier JF: Platelet-derived growth factor (pdgf) and receptor (pdgfr) expression in human meningiomas: Correlations with clinicopathological features and cytogenetic analysis. Neuropathol. Appl. Neurobiol. 1994, 20: 439-447, doi:10.1111/j.1365-2990.1994.tb00994.x.

49. Majumdar K,Radotra BD,Vasishta RK,Pathak A: Platelet-derived growth factor expression correlates with tumor grade and proliferative activity in human oligodendrogliomas. Surg. Neurol. 2009, 72: 54-60, doi:10.1016/j.surneu.2008.10.001. 
50. Nejjari M,Hafdi Z,Gouysse G,Fiorentino M,Beatrix O,Dumortier J,Pourreyron C,Barozzi C,D'Errico A,Grigioni WF,Scoazec JY: Expression, regulation, and function of alpha $\mathrm{v}$ integrins in hepatocellular carcinoma: An in vivo and in vitro study. Hepatology 2002, 36: 418-426, doi:10.1053/jhep.2002.34611.

51. Felding-Habermann B,Fransvea E,O’Toole TE,Manzuk L,Faha B,Hensler M: Involvement of tumor cell integrin alpha $\mathrm{v}$ beta 3 in hematogenous metastasis of human melanoma cells. Clin. Exp. Metastasis 2002, 19: 427-436.

52. Hosotani R,Kawaguchi M,Masui T,Koshiba T,Ida J,Fujimoto K, Wada M,Doi R,Imamura M: Expression of integrin alphavbeta3 in pancreatic carcinoma: Relation to mmp-2 activation and lymph node metastasis. Pancreas 2002, 25: e30-35.

53. Baum O,Hlushchuk R,Forster A,Greiner R,Clezardin P,Zhao Y,Djonov V,Gruber G: Increased invasive potential and up-regulation of mmp-2 in mda-mb-231 breast cancer cells expressing the beta3 integrin subunit. Int. J. Oncol. 2007, 30: 325-332.

54. Wenk CH,Ponce F,Guillermet S,Tenaud C,Boturyn D,Dumy P,Watrelot-Virieux D,Carozzo C,Josserand V,Coll JL: Near-infrared optical guided surgery of highly infiltrative fibrosarcomas in cats using an anti-alphavss3 integrin molecular probe. Cancer Lett. 2013, 334: 188-195, doi:10.1016/j.canlet.2012.10.041.

55. Bello L,Francolini M,Marthyn P,Zhang J,Carroll RS,Nikas DC,Strasser JF,Villani R,Cheresh DA,Black PM: Alpha(v)beta3 and alpha(v)beta5 integrin expression in glioma periphery. Neurosurgery 2001, 49: 380-389; discussion 390, doi:10.1097/00006123-200108000-00022.

\title{
EKSPRESIJA FAKTORA RASTA TROMBOCITA, NJIHOVIH RECEPTORA KAO I SUBJEDINICE ALFA INTEGRINA U POSTVAKCINALNIM SARKOMIMA MAČAKA NA MESTU INJEKCIJE
}

\author{
ISHTIAQ Ahmed, SOZMEN Mahmut
}

Smatra se da su sarkomi na mestu injekcije značajan patološki entitet u veterinarskoj onkologiji, naročito kod mačaka. Studija je ispitivala imunohistohemijsku ekspresiju faktora rasta A, poreklom iz trombocita (PDGFA), receptora za faktor rasta - alfa poreklom iz trombocita (PDGRF- $\alpha$ ) i integrin alfa subjedinice $\mathrm{v}$ u slučajevima sarkoma na mestu inokulacije (FISS). Ukupno je ispitano 14 parafinskih uzoraka, poreklom od prethodno dijagnostikovanih sarkoma mekih tkiva, iz podataka arhive departmana. Uzorci su standardno obrađeni i isečeni na isečke debljine od $5 \mu \mathrm{m}$ pomoću mikrokriotoma. Uzorci tkiva su bojeni standardnom hematoksilin-eozin, Alcian plavo-Periodic Acid Schiff (AB-PAS) i Mason-trihrom tehnikama bojenja kao i imunohistohemijski u cilju detekcije PDGFA, PDGR- $\alpha$ kao i integrin-alfa v. Većina tumora su po svojim karakteristikama bili fibrosarkomi $(n=13 / 14)$, osim u jednom slučaju miksoliposarkoma. Tumori su bili locirani na uobičajenim mestima inokulacije vakcina. Histološki u tumorima je uočena infiltracija mononuklearnim ćelijama, 
većinom limfocitima, a u centralnim regionima nekrotična područja promenljive veličine, i prisustvom većieg broja multinuklearnih gigantocita. AB-PAS bojenjem, uočeno je prisustvo miksoidnih ili mucinoznih regiona kod 8 od 14 tumora dok je trihrom bojenje ukazalo na varijabilnu količinu kolagene strome kod 12 od ukupno 14 tumora. Kod svih tumora, uočena je imunoreaktivnost na vimentin, pri čemu je reaktivnost na glatkomišični aktin uočena kod četiri, odnosno kod dva slučaja. Imunoekspresija PDGFA kao i PDGFR- $\alpha$ zapašena je u svih 14 slučajeva pri čemu je pozitivan nalaz na integrin alfa bio u 13 od 14 slučajeva. Rezultati studije ukazuju da je morfološki fenotip FISS prevashodno u tipu fibrosarkoma. PDGFA, njegovi receptori i ekspresija integrin alfa v su povećani u slučaju ovih tumora mačaka, što ukazuje na njihovu ulogu u patogenezi FISS. 